CAKRAWALA LINGUISTA

e-ISSN: 2597-9779 dan p-ISSN: 2597-9787

This work is licensed under

a Creative Commons Attribution-NonCommercial 4.0 International License.

\title{
The Lexicostatistic Study Of Culambacu Language With Tolaki Language
}

\section{La Ino Mbangi ${ }^{1}$, La Ode Sidu Marafad ${ }^{2}$ \\ University of Halu Oleo \\ Email: Unhalu39@yahoo.co.id}

Keywords :

language, lexicostatistic,

Culambacu, Tolaki

\begin{abstract}
Language Culambacu spoken by ethnic Culambacu contained in North Konawe district. This language has several dialects such as Lamonae dialect in Wiwirano Subdistrict, Landawe dialect in Oheo Subdistrict of North Konawe Regency, and Torete dialect is on the east coast of Konawe Regency in Waworaha Village. Tolaki language is spoken by ethnic tolaki located in Konawe District. This language has two dialects of Konawe dialect and Mekongga dialect. Based on the results of the analysis using lexicostatistic method found kinship relationship between Culambacu language with Tolaki language quantitatively is $39 \%$ vocabulary that is related to error rate 230. Both languages are separated from proto language estimated $3070 \pm 230$ years ago.
\end{abstract}

\section{INTRODUCTION}

The speakers of Culambacu language can be found in North Konawe District, Southeast Sulawesi Province. The Culambacu language consists of three dialects, the Lamonae dialect in Wiwirano Subdistrict and the Landawe dialect in Oheo Sub-district of Konawe Utara District, and the Torete dialect is on the east coast of Konawe District in Waworaha Village.

According to the local community, the Culambacu people in the village Culambacu District Wiwirano since the establishment of the Kingdom of Culambacu with the first king named Untolipu based in Wawoheo, Takupuno. The Culambacu people according to the local story are from seven brothers of six men one woman, the only woman living in Culambacu, while the six siblings are scattered to other areas.

According to the local community culambacu comes from the word cu means down and mbacu means stone. So, culambacu means down to the rock and the descent place is called Cinutu. There is also a saying that culambacu comes from the word horn which means bamboo and mbacu means stone. So, culambacu means bamboo stone. There is a mountain in Culambacu there is an old cemetery near him growing seven bamboo groves adjacent to each other. This bamboo tree does not develop until now, so it is most likely called stone bamboo because it does not grow or grow.

The Tolaki language is a large-sized regional language in Southeast Sulawesi, and plays a considerable role, especially in cultural life. As with other regional languages in Southeast Sulawesi, 
in Tolaki there are also some dialects; the Konawe dialect in Kendari Regency, and the Mekongga dialect in Kolaka District.

The Tolaki language user area includes (1) Kendari, (2) Mandonga, (3) Poasia, (4) Ranomeeto, (5) Moramo, (6) Lainea, (7) Tinanggea, (8) Lambuya, (9) Wawonii, (10) Unaaha, (11) Asera, (12) Lasolo, (13) Sampara, (14) Soropia.

Both of these languages to date have not been studied either synchronically or in diachronic. Through this paper will be the relationship of these two languages with diachronic approach. Whatever the purpose of this paper is to know how far the relationship between the two languages.

This research is based on comparative historical linguistic theory. The theory was developed by Jacob Grimm (1787-1863), Lehman (1972), Hock (1988), Bynon (1979). This theory is also called diachronic theory, which involves the analysis of the form and regularity of changes in common languages such as those accompanied by sound changes, to reconstruct the language of the past, the ancient language (proto) that lived on thousands of years before that. This ancient language (proto) is changed and broken into several derivative languages due to the place and time factor (Bynon, 1979: 54). These derived languages inherit the rules of the original language and will be different because of the development (innovation) that occurred later after the language is different (Bynon, 1979: 61).

The kinship relationship between the cognate languages in the comparative historical study can basically be proved on the basis of inherited elements of the language of origin or of protolanguage (Fernandez, 1996: 21). The concept of the origin or the proto language is not really a real form of language, but a form that is built up or re-assembled as a picture of a language's past. In other words, this concept is a theoretical idea that is designed in a very simple way to connect relative languages by using a number of rules (Bynon 1979: 71). Linguistic facts in the form of an equivalence order found in the languages of the relatives show evidence of a common authenticity that is inherited from the same ancestor (Bynon 1979: 47). Given the same inherited traits, the closeness of the relationship between the languages of the relatives can be found and the proto system can be traced.

The interrelatedness of inter language affinities in comparative studies is basically evident by the inherited elements of the native language or the proto language (Hock, 1988). The concept of the language of origin or proto language is not really a concrete form of language, but a form that is constructed up or re-assembled as a picture of a language's past. In other words, this concept is a theoretical idea that is designed in a very simple way to connect the systems of a common language by using a number of rules (Jeffers and Lehiste, 1970; Bynon: 1979: 71). The facts of language in the form of order, the correspondence found in the languages of the relatives shows evidence of a common authenticity that is inherited from the same ancestor (Bynon 1979: 47). Given the same inherited traits, the closeness of the relationship between the languages of the relatives can be found and the proto system can be traced.

\section{METHOD}

Prior to the determination of data collection methods, the research subjects should first be defined as informants. The technique of determining the research subjects used in the implementation of research in the field is a purposive sampling technique (Faisal, 1990: 56). The number of sample members is determined by three to five persons who can represent each of the user population of the language studied. Of these, one person acts as the main informant and the other as a counterpart informant. Furthermore, it is suggested that in the selection of samples, the informant must meet certain criteria, such as (1) having the capability of having the ability and ability, (2) being willing and having the time, (3) accessibility means easily reached or contacted, and (4) permissive means the informant allowed himself to be a source of information (Faisal, 1990: 58-61). In addition to these criteria, the informant must also fulfill several conditions. The requirements include (a) every member aged 35 65 years, (b) has normal speech and mental organ, (c) parent, wife or husband and the person is born or has never left his village for a long time, (d) have pride in their local languages, and (e) have a minimum education (SLTP) (Samarin, 1988: 55-67). 
It should be mentioned here that the number of informants above is used at the time of initial data collection, while at the time of collecting the data further the amount will be added. This is done considering the amount of advanced data to be collected far more when compared with the initial data, so it takes a longer time. To avoid boredom, ideally informants should be added. In the implementation, the informants were gathered into several groups and asked for information according to the ability and endurance of each group.

This study uses historical simcomparative and diakomparative analysis methods (Lass, 1969: 15). The syncomparative method is applied before using the diakomparative method in order to analyze the data of the cognate languages being researched synchronously. This method is used based on the fact that comparative historical research must begin with a synchronic approach. That is, in comparing relative languages, before being analyzed diachronically, the languages are first analyzed synchronously.

The method of syncomparative analysis emphasizes the phonemic description and the discovery of phonological change aspects descriptively. This analysis aims to find the phonemes, allophones and their variants, and the relationship of each phoneme in each of the phonological systems of the language studied (Antonsen 1990: 297). It is important to make the basis for the assumption that the language being studied is a related language, not the same language and not the language that is not related at all (Martinet, 1955 and Maulton, 1961 in Fisiak, ed, 1985).

The comparative analysis method is used as an advanced step to compare all the diachronic studied languages. Diachronic work is done in stages. First, the data in the form of a list of 200 Swadesh's basic vocabulary is analyzed quantitatively using lexicostatistic techniques. With this technique can be obtained the number of percentage of cognate each language (compare Crowley, 1987: 190). Based on the percentage of inter language cognate can be determined group members of a temporary nature of the languages studied. Second, the data are analyzed qualitatively by considering (1) pairs of words that are all identical phonemes, (2) couples having phonemic correspondences, (3) couples with phonetic similarities, (4) couples having one distinct phoneme. Keraf (1991) suggests taking the following three steps in reconstructing kin-language phonemes: (a) recording all the corresponding phonemic correspondences of language groups, (b) comparing the contrasting elements in the wider environment and looking for pairs (c) reconstruct each phoneme of the comparable word. Based on the qualitative analysis, the kinship geneality of the languages studied is defined definitively.

Lexicostatistic is one of the techniques of grouping languages or dialects that emphasize statistical calculations of words to know the number of similarity of comparable relatives' words (Grimes 1987 in Mead 1999). The lexicostatistics contains a list of the basic vocabulary of each language to be compared. Morris Swadesh proposes 200 universal basic vocabulary, which includes pronouns, number words, limb words (nature and activity), nature and surroundings and the tools of everyday culture.

Lexicostatistic as one of the method of language grouping has been widely used by experts / linguists in this world. This Method uses statistics in the form of numbers as the basis for sorting. The method tries to find the relationship of two or more languages by taking into account the elements of the equation that exist in the vocabulary. According to Nothofer (1990) lexicostatistic method has several advantages when compared to other methods. The advantages in question are (1) as a list of basic vocabulary that can quickly determine the kinship of one language (language relative), (2) as a grouping tool of language / dialect which is not as proto language similarly old / ancient, and (3 ) as a grouping tool / method that can be used in the early stages to determine the language classification. Furthermore, Nothofer (1990) sets out three basic assumptions of the lexicostatistic method, namely (1) the basic vocabulary is replaced with the same speed in all languages at the same time. According to this assumption that every 1,000 years about $18-20 \%$ of the basic vocabulary changes and applies equally to all languages simultaneously, (2) all of the basic vocabulary found on the basic vocabulary list is likely to change simultaneously, and (3) ) there is a so-called basic vocabulary that is generally accepted in every language of the world. 
The work of lexicostatistics follows the patterns suggested by Keraf (1990) namely, (1) accumulating a number of words from basic vocabulary, and (2) determining the basic pairs of basic vocabularies. Furthermore, the effort to determine the basic vocabulary follows the steps suggested by Keraf (1990) namely, (1) finding vocabulary that is not from the language / loan word, (2) having a single / free morpheme alone by isolating all bound morphemes, and (3) compare all pairs of words to determine pairs of words that are related to recurrence, co-occurrence, and analogy. Efforts to determine the pairs of closely related words are done by identifying all similar / similar pairs of words, phonetic-like pairs, pairs of corresponding words, and word pairs with only one phoneme difference in one phoneme.

\section{RESULTS AND DISCUSSIONS}

Kulambacu Language Religion and Tolaki Language Based on data obtained from informants, then can be done comparison to see the word relatives as in the following table.

Table 1. a related word in Culambacu and Tolaki Konawe

The percentage of kinship level of Culambacu language and tolaki language dialect konawe based on the data obtained and the provisions of the formula used to obtain the percentage of kinship, the following results are obtained:

$\mathrm{H}=\frac{j}{g} \mathrm{x} 100 \%$

$\mathrm{H}=\frac{77}{198} \times 100 \%=\frac{7.700}{198}=38,8889=39 \%$

$\mathrm{R}=86 \%$

Calculate long time split

$$
\begin{aligned}
t=\frac{\log c}{2 \log r}=\frac{\log 0,39}{2 \log 0,86}= & \frac{-0,40}{-0,13} \\
& =3,07 \times 1000 \\
& =3070
\end{aligned}
$$

Calculate period error

$$
\begin{aligned}
S & =\frac{\sqrt{c(1-c)}}{n}=\frac{\sqrt{0,39(1-0,39)}}{198} \\
& =\frac{\sqrt{0,39 \times 0,61}}{198}=\frac{\sqrt{0,23}}{198}=\sqrt{0,001}=0,03
\end{aligned}
$$

Calculate length of time apart once calculated period error

$$
\begin{aligned}
\mathrm{t}_{1} & =\frac{\log c+\sqrt{C(1-c) / m}}{2 \log r} \\
& =\frac{\log o, 39+0,03}{-0,13} \\
& =\frac{-0,40+0,03}{-0,13}=\frac{-0,37}{-0,13} \\
& =2,84 \times 1000 \\
& =2840
\end{aligned}
$$

Calculate separation time-length of time separation

$\mathrm{t}-\mathrm{t} 1=3070-2840$

$=230$

So the length of time the two languages are separated is

Between $3070 \pm 230$ and the year $2840 \pm 230$ 


\section{CONCLUSION AND SUGGESTION}

Based on the results of the above discussion can be concluded that the two languages are related. The percentage of relatives of both languages is $39 \%$. Then the two languages split from the proto estimated between $3070 \pm 230$ years ago.

\section{REFERENCES}

Arlotto, Anthony. (1981). Introduction to Historical Linguistics. Boston: Houghton Mifflin. Bynon, Theodora. (1990). Historical Linguistics. London: Cambridge University Press.

Crowly. Terry. (1997). An Introduction to Historical Linguistic. Port Moresby: University of Papua New Guinea Press.

Dyen, Isidore. (1975). Linguistic Subgrouping and Lexicostatistic. The Hague Paris: Mouton.

Fasisal, Sanapiah. (1990). Penelitian Kualitatif: Dasar-Dasar dan Aplikasi. Malang: YA3

Fernandes,Inyo Yos. (1996). Relasi Historis Kekerabatan bahasa Flores. Kajian Linguistik Historis Komparatif terhadap sembilan bahasa di Flores. Flores: Nusa Dua

Fisiak, Jacek (ed). (1985). Historical Semantics: Histprical Word-Formation. Berlin: Mounton Publishers.

Hock, Hans Henrich. (1988). Principes of Historical Linguistics. Berlin-New York-Amsterdam: Mouton de Gruyter.

Jeffers, Ribert J \& Lehiste. (1979). Principles and Method For Historical Linguistics. Cambridge: The MIT Press.

Keraf, Gorys. (1996). Linguistik Bandingan Historis. Jakarta: PT Gramedia Pustaka Utama

La Ino and La Ode Sidu. (2016) "Reconstruction of Protolanguage Blagar and Pura in Alor Regencyin East Nusa Tenggara in Indonesia (The Study of Historical Linguistics)" Artikel presented in International Linguistic and Language Studies Conference in Istanbul Turki June $24-25$.

La Ino dan La Ode Sidu. (2016). "Kinship Relations in Kulisusu Language, Waonii Language, and Moronene Language' Makalah disajikan pada The 26th Annual Meeting of the Southeast Asian Linguistik Society tanggal 26-28 Mei 2016 di Manila Phipina.

La Ino. (2004). "Pengelompokan Genetis Bahasa Blagar, Pura, dan Retta di Kabupaten Alor Provinsi Nusa Tenggara Timur.” Tesis untuk Program Pascasarjana. Universitas Udayana.

La Ino. (2013). Protobahasa Modebur, Kaera, dan Teiwa Bahasa Kerabat Non Austronesia di Pulau Pantar Nusa Tenggara Timur" Disertasi untuk Program Pascasarjana Universitas Udayana

La Ino. (2014). "Kekerbatan BahasaMuna, Wolio, dan Tolaki dalam Angka: Suatu Analisis Leksikostatistik" dalam Jurna 1Langua Vol. 4 No. 1 April 2014. Lembaga Kajian Ekolinguistik; Medan.

La Ino. (2015a). "Pemanfaatan Linguistik Historis Komparatif dalam Pemetaan Bahasa-Bahasa Nusantara" dalam jurnal Retorika Vol. 1 Nomor 2 Oktober 2015. Halaman 359-374.

La Ino. 2015b. Deskripsi Fonem Bahasa-Bahasa di Sulawesi Tenggara. Yogyakarta:Pustaka:Puitika.

La Ino. 2015c. "Genetic Relationship Language Muna, Busoa, and Kambowa in Southeast Sulawesi" (Linguistic Historical Comparative Study). Makalah disajiman pada Seminar Internasional di Universitas Andalas tanggal 12--13 Agustus 2015.

La Ino. (2016). "The Reconstruction of Protolanguage Muna and Kambowa" in International Journal of Linguistics Literature and Culture (IJLLC), Vol. 2 No. 3 September 2016 ISSN: 2455-8028 page $125-140$.

Samarin, William J. (1988). Ilmu Bahasa Lapangan. Terjemahan J.S. Badudu. Seri ILDEP: Yogyakarta. Kanisius.

Stokhof, W.A.L.(ed). (1980). Holle List: Vocabularies in Languages of Indonesia. Vol. 1:Introductory Volume. PL.D. 17.

Swadesh, Morris. (1972). The Origin and Diversification of Language. London: Routledge \& Kegal Paul. 
